\title{
Archaeology in 1984
}

\author{
IAN HODDER
}

\begin{abstract}
In this stimulating and provocative article, Dr Ian Hodder, Lecturer in Archaeology in the University of Cambridge, asks many pertinent questions. Is archaeology a soft science or an expensive humanity? What is the rôle of the distant past in modern Western Society? Is the past that interests archaeologists of interest to the general public, many of whom may think archaeology useless and a complete waste of money? Are the pasts which archaeologists create socially neutral? In suggesting answers to some of these important questions he argues for a post-processual or contextual archaeology in which interpretations of the past should take greater account of meaning, the individual, culture and history. He begins, appropriately enough, with a quotation from George Orwell's 'Nineteen eighty-four'.
\end{abstract}

\begin{abstract}
'. . . the lie passed into history and became truth. "Who controls the past', ran the Party slogan, 'controls the future: who controls the present controls the past.' And yet the past, though of its nature alterable, never had been altered. Whatever was true now was true from everlasting to everlasting.' (George Orwell, Nineteen Eighty-Four, Penguin, p. 3I).
\end{abstract}

Recently there has been an increased interest in the archaeological recovery of past ideas, reconstructing the minds of humans long dead (Leone, 1982 ; Renfrew, 1982b). The notion that archaeologists study artifacts made by Man which were the product of the human mind and human craftsmanship' (Daniel, 1962, 30) and 'projections of his mind and embodiments of his history' (Clark, I 975 , 9; see also Childe, 1949) is of course not new and is emphasized in Collingwood's (I956) contribution to the idealist view of history. Yet in the ladder of inference outlined by Hawkes (1954) the ideational realm was seen as being the most difficult to grasp and for many 'new archaeologists', at least initially, attempts at getting into prehistoric people's heads were decried as palaeopsychology (Binford, 1965 , 203-10) and for Binford (1982, 162) archaeological reconstruction of mental phenomena is still deemed inappropriate. As Leone ( 1982 ) has cogently argued, the renewed attempts at reconstructing mind take varied paths from the symbolic functionalism of, for example, Wobst ( 1977 ), Fritz (1978), Hall (r977), Flannery and Marcus (1976) and
Friedel (198I), to the structuralism of LeroiGourhan (1967), Deetz (1977) and Glassie (1975), the cognitive accounts of Kehoe (1973) or Muller (1977), the various materialist studies of ideology (Tilley, 1981; Rowlands, I980; Shennan, 1982) or of archaeological interpretations as ideology (Meltzer, I98I; Leone, I978). Often, however, these studies appear to side-step important epistemological issues raised by the 'archaeology of mind'. In particular, how can a scientific archaeology devoted to the testing of theories against data cope with verifying statements about ideas in prehistoric people's heads?

While the reconstruction of past ideas brings such a question to the fore it can be claimed that the dilemma has always been present, if not fully recognized, in 'scientific' archaeology. All statements about the past involve adding to archaeological data in the process of interpretation. It is always a question of saying more than is actually there, from the stage of interpreting colours and textures on a trench wall in an archaeological excavation to reconstructing social systems. Leaps of faith are necessarily made since much of what archaeologists reconstruct is unobservable. This is particularly clear in much recent 'processual' archaeology. As Binford (1982, 162) has commented, the frequent references by social archaeologists to prestige systems, status, display, rank or conspicuous consumption, for example in burial studies, involve 
notions of values in the heads of prehistoric individuals. Equally, within ecological archaeology, assumptions of minimizing effort, least risk, and maximizing resources cannot in themselves be verified in archaeological data. 'The implications of such assumptions can, of course, be 'tested' in archaeological data, in the same way that most ideas in the mind have effects on the material world. The effects can be tested but to do so is tautological and self-fulfilling, and the values and ideas themselves remain beyond observation.

The re-emergence of an interest in past ideas thus brings to the fore an ever-present problem which the archaeological emphasis on objectivity and the separation of theory and data, evident from Childe (1925) to Renfrew (I982a), rarely faced (see, however, Childe, i 949). It is altogether remarkable that, without any ability adequately to test their reconstructions of the past, archaeologists have come to reach agreement and consensus on many issues. It may be helpful to refer to an example of this process.

A major arena of recent archaeological research has been the exchange of prehistoric artifacts. Basic texts of the reconstruction of the social mechanisms involved in exchange have been written (Earle \& Ericson, 1977; 1982) and general theories of exchange have been built (Pryor, 1977; Sahlins, 1972). Much of the interest in archaeology has centred on prehistoric Europe where the scientific armoury has been thrown at the sourcing of, for example, obsidian, pottery, stone axes, shells (Renfrew, Dixon \& Cann, I968; Peacock, I969; 1977; Shackleton and Renfrew, 1970; Cummins, 1979). Statistical techniques have been applied to the interpretation of fall-off curves, and the debate has spread widely with numerous articles written (for example, Renfrew, 1977; Sidrys, 1977; Hodder, 1974; McBryde, 1978; Clarke, 1978; Ammerman, I 979; McVicar, I982). Much of the work in Europe has taken an early article by Renfrew ( 1969 ) as a starting point, and the underlying assumption has been throughout that artifacts were passed from person to person across wide areas. This idea was initially encouraged by Grahame Clark's ( I965) $^{2}$ acquaintance with Australian ethnographic material, and the exchange of prehistoric artifacts has continually been supported by ethnographic models. All the work on the movement of prehistoric artifacts in Europe assumes that exchange occurred. A large literature has been built on an unverifiable assumption. It is simply impossible to test whether prehistoric artifacts moved from source to destination by exchange from person to person or whether, on the other hand, individuals went directly to the source. Recently I thought such a test would be possible in relation to British neolithic stone axes and it was suggested (Hodder \& Lane, 1982) that if axes were exchanged from person to person, being used and resharpened through time, they should get smaller with increasing distance from the source. 'This 'test' was successful since axes did prove to get smaller with increasing distance from their source, but in the end it is apparent that the assumption of exchange itself has not been tested. If axes were obtained directly from the source it is possible that individuals farther from the source would make the journey less frequently than individuals nearer the source, they would use and resharpen their axes for longer before replacing them, so that, once again, the sizes of axes would decrease with increasing distance from the source. Certainly other, more ingenious 'tests' will be suggested, but ultimately the hypothesis of prehistoric exchange is about the unobservable. It involves 'adding to' that which is observed. The amount of analytical, computer and research time that has been spent on questions of prehistoric exchange is enormous. It has been possible to spend so many resources because of a consensus in the archaeological community which accepts, somewhat mysteriously, not to question a particular assumption. As far as I am aware no-one in the literature has suggested that prehistoric exchange did not occur.

It is not my concern here to examine the process of reaching consensus, why some assumptions are accepted and others rejected by archaeologists, nor to account for the sociology and self-maintenance of a discipline. But I do wish to emphasize further that archaeologists need to face squarely the notion that archaeological hypotheses are not tested on archaeological data and that theory and data do not confront each other within an objective science of archaeology. Renfrew (1982a, I43) has restated 'the old relationship between theory and data' as:

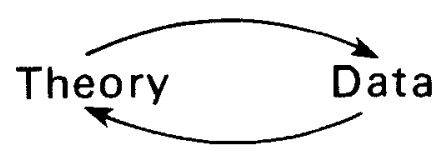

Examples such as the following appear to support such a picture of the way archaeologists work. 
Imagine that an archaeologist has an hypothesis that a particular unexcavated site had a huntergatherer economy. This hypothesis may have been suggested because of the type of soil around the site and because of various theories concerning resource utilization. The site is then excavated in order to test the theory through examination of the faunal remains. Imagine that the excavator recovers few wild animal bones but that the bones of domesticated cattle, sheep, goat and pig are well represented. Numerous carbonized cereal grains are recovered as well as querns and other artifacts of a farming economy. Surely here a theory has been proposed, tested against the data, proved false, leading to change in the theory? 'The confrontation and objective testing of theory against data is here apparent. Or is it?

Closer examination shows that the huntergatherer hypothesis has not been tested against archaeological data, but against an edifice of auxiliary theories and assumptions which archaeologists have agreed not to question. There is only space here to refer to a few of these assumptions. First, there are theories concerning stratigraphical relationships and the nature of archaeological sites and layers. The discussion of economies assumes that the interpretation of soil and colour changes, associations of artifacts, are correct. Second, it is assumed that an 'assemblage' in a 'layer' represents 'an economy' whereas, for example, it is possible that the 'closed assemblage' is a palimpsest, representing the activities of different groups or individuals with a variety of different economies. Third, there are problems in the definition of wild or domestic animals. What is meant by 'domesticated'? Different criteria can be used to specify domestication and the choice of method is theorydependent. Fourth, domesticated resources on the site could have been obtained by exchange while dependence on wild resources may be underrepresented because wild animals were processed

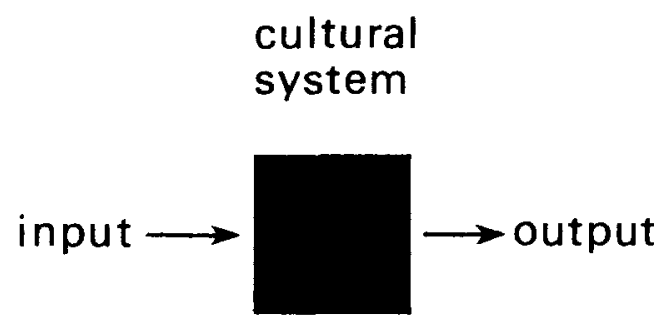

THE BLACK BOX off sites or at subsidiary sites. To examine all such assumptions would involve writing a text of archaeological theory and method but I hope that enough has been said to demonstrate that archaeological theories are 'tested', not on archaeological data, but on other archaeological theories. As in the exchange example, assumption is built upon assumption and a consensus is reached, but ultimately statements about the past are about the unobservable and they are unverifiable.

Within processual or systems archaeology the problem of testing theories about the unobservable was usefully discussed in relation to the incomplete and very large Black Box (Clarke, I968, 59-62). Leach (1973) stated how difficult it was for archaeologists to look into the box with anything more than guesswork, but systems analysis suggested that correlations could be observed between inputs and outputs and the predictability of such relationships in the past and present could be used to test ideas about the contents of the box (Clarke, $1979,5 \mathrm{r}$ ). Much of the new archaeology was characterized by a 'certainty' in the reconstruction of the past as long as scientific methods were pursued. The optimism of Binford's (1962) view that archaeological assemblages present a picture of the total extinct cultural system is distinctive. More recently, it might be suggested, doubts are increasing: Flannery's ( 1973 ) 'young fogeys' abound, mistrustful of complex social interpretations of the past.

In view of the discussion above it might be appropriate to replace the Black Box by a much less certain box, the appearance of which depends on the point of view of the observer. The problem to be faced by archaeologists is that the objects or systems they observe depend on the theories they are supposedly testing. The boundaries and nature of the systems have to be specified by the analyst. Theory and data are not opposed and they are never confronted. Rather, data are observed within interpretation and theory.

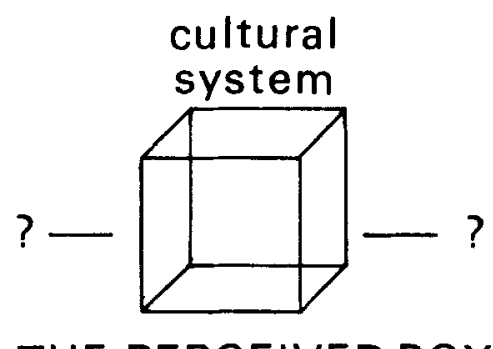

THE PERCEIVED BOX 
It might be countered that surely archaeologists can count 'things', showing similarities and differences across space and time in archaeological assemblages. But the 'things' one counts are always classes of things constructed by the observer. Before we can count we need to define classes or types. As David Clarke noted ( $1968,{ }_{15}$ ), there are perhaps limitless numbers of different attributes to measure on objects, and the classes or types of object that are produced depend on what attributes one thinks relevant. For example, we may have a theory that matrilocal residence leads to localized styles of pottery within a site (Longacre, 1970). To 'test' this theory in prehistory it is thought necessary to use the decoration or shapes of potsherds. But depending on how we describe and 'observe' the sherds, different types and degrees of spatial clustering within sites will emerge. All sherds are similar in some respects but different in others. We cannot measure everything, so what are we to emphasize in the analysis? There can be no independent theory which allows us to decide what to measure or count since the choice of such a theory is itself theory-dependent. In any case, 'independent' or 'middle range' theories are themselves based, in ethnoarchaeological studies of present-day societies, on moving beyond the data to cultural inferences. Once again, archaeologists can only work by consensus, building up assumption upon assumption.

Similar problems of verification are faced in most disciplines, and the issues raised have been widely discussed (for example, Feyerabend, r975; Kuhn, 1962; Berger \& Luckmann, 1967; Gregory, 1978), but the example of archaeology is of interest because it presents the problems in a particularly acute form. The leaps of faith that have to be made in interpreting archaeological data are great because so little is known and yet so much is said. It might be hoped that difficulties encountered in other disciplines can be squarely faced and resolutions sought in archaeology.

To summarize, the dilemma apparent for archaeologists is that there is a widespread desire for science and objective tests, a fear of speculation and the subjective, and yet we want to say something about the past. In particular, in recent years, it has become clear that if we want to say anything interesting about the past we must include statements about prehistoric ideas. Yet to say anything about the past, and about past ideas, involves moving beyond the data to interpret them, and there can be no testing of these interpretations because the data themselves are formulated within and are part of the same argument as the theories. Speculation and the subjective are therefore part of the 'scientific' process.

However, the dilemma only occurs if archaeology is seen as a science. The 'problem' is of the archaeologists' own making. If archaeology is seen properly as a cultural and social product the 'problem' dissolves. The data of the past are observed and have meaning within a present social and cultural context. Archaeology is a discipline with specified methods, rigorously defined, and theories of its own. It is a science in the general sense of using explicit and repeatable procedures. It contributes to debates about the nature of humankind. But it is not a science if by that is meant a discipline in which objective truth can be provided or approached. Rather, archaeology does and must continue to play an active social role in the various cultures in which it is produced. In the West scientific archaeology has, if anything, had the danger of removing archaeology from any ability to make a relevant contribution to the modern world, both because of the neutral, apolitical aura which it has claimed as a science, and because of the scientific terminology and specialization with which it has surrounded itself. Yet changing interpretations of the past can be seen to be linked to the changing expectations and attitudes of archaeologists and contemporary society (Leone, 1978; Meltzer, r981; Trigger, 1980).

The notion that the past is an active product of the present, however, raises problems and dilemmas of its own. In particular, if archaeologists cannot be seen as providing neutral information for the public, what social responsibilities are involved? The questions that come to the fore include: what type of past do people want, should archaeologists provide a past that supports (legitimates) or disturbs present outlooks, which sections of society do archaeologists write for, and what are the implications of Western archaeologists working in developing countries? Such questions seem particularly important today when archaeology, as a peripheral non-school subject, is under heavy pressure as either a soft science or an expensive humanity. In Britain, at least, the call for accountability requires academic archaeologists to consider more carefully their relationship with the public.

Yet how are archaeology and archaeologists 
viewed by the public and what is the rôle of the distant past in modern Western society? Such questions have been asked in developing countries (for example, Miller, 1980). In Britain many archaeologists probably feel that they have a good impression of public attitudes from adult education classes, from the popularity of Horizon and the Mary Rose (although see Parker Pearson, 1983), from talking to the public at the side of excavation trenches, or from perusing the pages of Popular Archaeology. Yet as producers we are probably not ideally placed to assess the product. It is probably the case that most professional archaeologists come from a fairly limited range of social backgrounds. The past that interests them (us) may not be of such interest to others.

For varied reasons, then, it would be of value to examine how different views of the past and of archaeologists relate to social and cultural backgrounds. At present a number of surveys are being carried out in England* in order to obtain a fuller picture of the place of archaeology and the distant past in contemporary English society. A small pilot study has already been undertaken by an independent research group $\dagger$ in Cambridge and I will briefly refer to the type of result that is emerging.

In general, the survey suggests that professionals with university or other higher education tend to be more interested in archaeology, to think that people need a distant past and that spending money on archaeology is worthwhile. Individuals in unskilled employment and who have left school at an early age are more likely to feel that people do not need a distant past, and that archaeology is 'generally useless' and a 'complete waste of money'. Other differences between social groups in definitions of archaeology and in the aspects of the past that are found interesting were also noted. Whatever the reasons, educational, cultural or social, for such differences, it is clear that we cannot assume that the stories we are writing are socially neutral. There is a need to examine carefully the effects of the past we reconstruct.

An example of the assumptions that archaeologists make without regard to social differences can be taken from the publicity produced by STOP, the

- These surveys in several British cities are being coordinated by Peter Stone (Southampton), Mike Parker Pearson and the author (Cambridge).

$\dagger$ The pilot study was carried out by the Cambridge Research Cooperative for Mike Parker Pearson and the author. Informants were drawn at random from the electoral register. campaign against the plundering of Britain's past. This national movement against treasure hunting is supported by most of the major archaeological bodies such as the CBA, the Museums Association, Rescue, the Association of County Archaeological Officers and the Standing Conference of Unit Managers. Under the heading 'the purpose of archaeology' the publicity pamphlet claims: 'we all need the stability which comes from a thorough knowledge of our own heritage', and further, 'the results of archaeologists' work ... increase our understanding of the past and ... deepen our sense of belonging in the present.' While this may be the view of certain groups in society, and it may be the consensus of archaeologists themselves, it is not a natural truth that can be taken for granted. At least the type of archaeology that archaeologists write may not be easily justified to many sections of society. A notion of social responsibility, brought to the fore by disillusion with the vision of archaeology as an objective science, implies that archaeologists should achieve some general understanding of the social and cultural context of the past they write.

It might even be claimed that widely circulated statements such as that provided by STOP have the danger of adding to social divisions within our society. While metal detectors and treasure hunters are at times described as 'rapists of the national heritage', an alternative viewpoint is expressed in the pages of the magazine Treasure Hunting. 'Professional archaeologists are university trained academics. With a few notable exceptions, they are, by preference, totally out-of-touch with the general public. During the past 20 years they have made it their business to complicate the story of Britain's ancient history ... . with the intention of securing the futures of their own academic careers . . The media's files are full of bumph which perpetuates the myth that every newly-qualified professional archaeologist gets a brightly polished halo with his university degree, along with a licence to 'salvage the nation's heritage', whereas the crime of 'people's archaeologists' is that 'they have no academic qualifications and ... therefore no right to an interest in British history' (Treasure Hunting, $1982,9)$. Perhaps some of us academics may be feeling our haloes a bit tarnished and may be wondering, without the comfort of 'objective science' to hide behind, how archaeology could play a more active part in society. The quotes from sTop and Treasure Hunting seem infused with differences in attitudes that have a social and cultural 
basis and which can be linked to mistrust and contempt glimpsed throughout a broad social arena. The survey of attitudes to archaeology and the past referred to above is a first stage in the process of understanding such differences and their social contexts so that, whatever political stance a particular archaeologist takes, (s)he can at least have a clearer, if not more responsible, idea of the social impact of the past (s)he reconstructs.

\section{CONCLUSION}

I have argued elsewhere (Hodder, I982) that interpretations of the past should take greater account of meaning, the individual, culture and history. These claims for a 'post-processual' or 'contextual' archaeology have been argued for 'academic' reasons to do with the construction of explanations, the inadequacy of the concepts of system and adaptation, the importance of culture in human nature, the central role of intentionality and so on. The stance is also taken because as an historical and, only in a broad sense, scientific discipline archaeology is best able to contribute its data on long sequences of cultural change within local areas to general understanding of the relationships between historical and cultural context and social change. Yet ultimately the claims for develop ments in archaeology are political in origin in three respects.

(I) At its worst the scientific 'new archaeology' raised an image of Man the passive and efficient animal controlled by laws which cannot be usurped. A timeless past was produced in which all societies could be described in terms of their 'technologistical' control over nature. The human past legitimated and made universal the principles of the technocratic West. In contrast, the past can be used to emphasize the historical contextuality of rationality and to engender respect for the individual, actively and meaningfully negotiating and creating social position.

(2) The emphases on science and cross-cultural generalization have been associated with an ever increasing split between theory and practice, between interpretation and excavation. Field archaeology is devalued and decried as technique, while theoretical archaeology is viewed from the outside as suspicious and remote. Popular interest which derives from 'digging up pots and bones' is divorced from ivory-tower ponderings about the meaning of the past. There are individuals who successfully cross the divide, but alienation is widespread. Yet if data are seen as dependent on theory, then excavation must be valued as an interpretive experience rather than a technique. We are all theoreticians. Equally, cross-cultural behavioural and evolutionary theories involve seeing the data from the past, such as the great civilizations of Egypt and the Indus, and the hunter-gatherers of Scandinavia, as mere examples of general social processes such as segregation, centralization and hypercoherence. The emphasis on cultural context advocated here relocates the objects from the past in the historically specific rather than in the theoretically abstract. The unique cultural achievement of Egyptian civilization is seen as having an interest in its own right. In this way there is a potential for the popular interest in the past through the experience of the concrete to be retained in the forming of abstract theories. We are all theoreticians but we also deal in data. This is not to claim that the data are independent of theory, but to state that our theories must be better moulded to the historically specific data.

(3) The notion of 'archaeology as science' legitimated the professional theoretician in the provision of neutral knowledge. Even if such knowledge might be used in planning the future, examples such as Hiroshima encouraged a separation of scientific theory and its social use. The split between theory and data described above is linked to that between knowledge and social process. The academic prehistorian hands out professional qualifications in the manipulation of abstract knowledge and his/her position depends on maintaining the aura of the specialist. In fact, however, such control of knowledge can amount to a form of hidden social control, in which one view of the past is seen as correct, in objective terms. The interests of one social class are seen as universal and the implications of Orwell's statement, quoted at the beginning of this article, loom before us. We have seen that there is no external, objective basis for saying that any one theory, well argued and coherent internally and 'fitting' to the data, is any better than another theory, equally well argued but based on different assumptions. The result of this relativism is not anarchy, if by that is meant that an endless series of arbitrary pasts will be produced. Rather, different pasts will be constructed within different but limited sets of social interests. There are signs that groups other than white, Anglo-Saxon, protestant, male, middle class intellectuals want to write their own pasts. Other social groups in England, women 
in England and America, ethnic minorities and archaeologists in less-developed countries are beginning to make claims to their own archaeology . They should be encouraged to develop their own observational, methodological and historical theories for reconstructing the past so that their social and cultural experiences in archaeology can be actively involved in social debate. If these different but coherent viewpoints can be discussed openly, then the past will play a rôle in unearthing and objectifying alternative viewpoints and social dispositions, contributing to social change. The past is everybody's past and by releasing it the dangers of Orwell's totalitarianism are lessened and the central rôle of the past is assured. But what this strategy implies for professional archaeology as an institution is not clear. From one point of view, the concerns of alternative social groups will increasingly force the Western professional archaeologist to be involved with and supported by a restricted set of social interests. From this angle, communication of the past by archaeologists, leading to wider popular appeal, will result in appropriation of the past by other social interests so that Western professional archaeologists serve a diminishing public. On the other hand, it remains possible that flexible training and understanding can be engendered in an archaeological community motivated, not by fears of anarchy and attacks on the control of neutral knowledge, but by the vision of the past as an arena for the playing out of different social values and interests.

\section{BIBLIOGRAPHY}

AMMERMAN, A. 1979. A study of obsidian exchange networks in Calabria, World Archaeology, xI, 95-1ro.

BERGER, P. \& T. LUCKMANN. I967. The social construction of reality (Harmondsworth).

BINFORD, L. R. 1962. Archaeology as anthropology, dmerican Antiquity, XXvin $217^{-25}$.

1965. Archaeological systematics and the study of culture process, American Antiquity, xxxI, 203-10.

1982. Meaning, inference and the material record, in (eds) $\mathrm{C}$. Renfrew \& S. Shennan, Ranking, resource and exchange (Cambridge).

CHILDE, v. G. 1925. The dawn of European civilisation (London). 1949. Social worlds of knowledge (Oxford).

Clark, J. G. D. 1965. Traffic in stone axe and adze blades, Economic History Review, xvil, 1-28.

1975. The earlier stone age settlement of Scandinavia (Cambridge).

CLARK, J. R. I978. Measuring changes in the ease of trade with archaeological data: an analysis of coins found at Dura Europus in Syria, Professional Geographer, xxx, 256-63.

CLARKE, D. L. 1968. Analytical archaeology (London).

1979. Analytical archaeologist. Collected papers of David Clarke (London).

COLLINGWOOD, R. 1956. The idea of history (Oxford).

cummins, w A. I979. Neolithic stone axes: distribution and trade in England and Wales, in (eds) T. H. McK. Clough \& W. A. Cummins, Stone axe studies (CBA Research Report 23). DANIEL, G. E. I962. The idea of prehistory (Harmondsworth). DEETZ, J. 1977. In small things forgotten (Garden City).

EARLE, T. K. \& J. E. ERICSON. I 977 . Exchange systems in prehistory (New York).

1982. Contexts for prehistoric exchange (New York).

FEYERABEND, P. 1975. Against method (London).

FLANNERY, K. v. 1973. Archaeology with a capital S, in (eds) C. L. Redman, et al., Research and theory in current archaeology (New York).

FLANNERY, K. v. 3. Marcus. 1976. Formative Oaxaka and the Zapotek cosmos, American Scientist, LxIv, 374-83.

FRIEDEL, D. A. 1981. Civilisation as a state of mind, in (eds) G. Jones \& R. Kautz, Transformations to statehood (Cambridge).
FRITz, J. M. 1978. Palaeopsychology today: ideational systems and human adaptation in prehistory, in (eds) C. Redman, et al., Social archaeology (New York).

GLASSIE, H. 1975. Folk housing of Middle Virginia (Knoxville).

GREGORY, D. 1978. Ideology, science and human geography (London).

HALL, R. L. I977. An anthropocentric perspective for eastern United States prehistory, American Antiquity, XLII, 499518.

HAWKES, C. 1954. Archaeological theory and method: some suggestions from the Old World, American Anthropologist, LVI, $155-68$.

HODDER, I. 1974. Regression analysis of some trade and marketing patterns, World Archaeology, vi, i 72-89.

1982. Theoretical archaeology: a reactionary view, in (ed.) 1 . Hodder, Symbolic and structural archaeology (Cambridge).

HODDER, I. \& P. LANE. 1982. A contextual examination of neolithic axe distribution in Britain, in (eds) J. E. Ericson and T. K. Earle, Contexts for prehistoric exchange (New York).

KEHOE, А. В. \& T. F. 1973. Cognitive models for archaeological interpretation, American Antiquity, xxxvirI, 150-4.

KUHN, T. 1962. The structure of scientific revolutions (Chicago).

LEACH, E. 1973. Concluding address, in (ed.) C. Renfrew, Explanation of culture change (London).

LEONE, M. P. 1978. Time in American archaeology, in (eds) C. Redman et al., Social archaeology (New York).

1982. Some opinions about recovering mind, American Antiquity, xLvir, 742-6o.

LEROI-GOURHAN, A. I 967 . The art of prehistoric man in western Europe (London).

LONGACRE, w, 1970. Archaeology as anthropology, Anthropological Papers of the University of Arizona, i 7 ('Tucson).

MCBRYDE, 1. 1978. Wil-im-ee Moor-ring. Or where do axes come from? Mankind, XI, 354-82.

MCVICAR, J. 1982. 'The spatial analysis of axe size and the Scottish axe distribution, Archaeological Reviews from Cambridge, I, $30-45$.

MELTZER, D. J. I981. Ideology and material culture, in (eds) R. A. Gould \& M. B. Schiffer, Modem material culture, the archaeology of us (New York). 
MILLER, D. I980. Archaeology and development, Current Anthropology, xxi, 709-26.

MULLER, J. 1977. Individual variation in art styles, in (eds) J. Hill \& J. Gunn, The individual in prehistory (New York).

PARKer pearson, M. 1983. 'Roses' are read, my love, when violence is news. . , Royal Anthropological Institute Newsletter, $\mathrm{LV}, 5$

PEACOCK, D. F. S. 1969 . Neolithic pottery production in Cornwall, Antiquity, XLIII, I45-9.

1977. Pottery and early commerce (London).

PRYOR, F. L. 1977. The origins of the economy' (New York).

RENFREW, A. C. 1969 . Trade and culture process in European prehistory, Current Anthropology, x, I 5 I-69.

1977. Alternative models for exchange and spatial distribution, in (eds) T. K. Earle \& J. Ericson, Exchange systems in prehistory (New York).

I982a. Discussion: contrasting paradigms, in (eds) A. C. Renfrew \& S. Shennan, Ranking, resource and exchange (Cambridge).

1982b. Towards an archaeology of mind (Cambridge).

RENFREW, A. C., J. E. DIXON \& J. R. CANN, I 668 . Further analyses of Near Eastern obsidians, Proc. Prehist. Soc., xxxiv, 3I9-3I.

\section{Book Chronicle continued from p. 24}

Romans in Britain by Rodney Legg. London: Heinemann, 1983. 276 pp., illus. £12.95.

Economic Anthropology: topics and theories edited by Sutti Ortiz. Monographs in Economic Anthropology, No. 1. Lanham: University Press of America, 1983.429 pp. $\$ 27.50$ hardback, $\$ 15.75$ soft covers.

The Mirror, the Rabbit, and the Bundle: 'Accession' Expressions and the Classic Maya Inscriptions by Linda Schele and Jeffrey H. Miller. Studies in Pre-Columbian Art and Archaeology, No. ${ }_{5}$ Washington D.C.: Dumbarton Oaks Research Library and Collection, 1983.99 pp., 33 figs.

Four Lienzos of the Coixtlahuaca Valley by Ross Parmenter. Studies in Pre-Columbian Art and Archaeology, No. 26. Washington D.C.: Dumbarton Oaks Research Library and Collection, 1982. 81 pp., 3 pls., 43 figs.

Roman Britain from the Air by S. S. Frere \& J. K. S. St Joseph. Cambridge Air Survevs. Cambridge: University Press, 1983.232 pp., 142 pls., 18 figs. £15.00.

Progrès récents dans l'étude du Néolithique ancien edited by Sigfried J. De Laet. Dissertationes Archaeologicae Gandenses Vol. XXI. Bruges: De Tempel, 1983. $126 \mathrm{pp}$., some figs.

London: City of the Romans by Ralph Merrifield. London: Batsford, 1983. 288 pp., 60 pls., 40 figs. E. 14.95 .

Structure and cognition in art edited by Dorothy K. Washburn. New Directions in Archaeology. Cambridge: University Press, 1983. 170 pp., many figs. $£ 22.50$
ROWLANDS, M. J. I980. Kinship, alliance and exchange in the European Bronze Age, in (eds) ]. Barrett \& R. Bradley, Settlement and society in the British Later Bronze Age (BAR British Series 83).

SAHLINS, M. D. 1972. Stone age economics (Chicago).

SHACKLETON, N. \& C. RENFREW. I970. Neolithic trade routes re-aligned by oxygen isotope analysis, Nature, ccxxvin, I062-1065.

SHENNAN, S, r982. Ideology, change and the European Early Bronze Age, in (ed.) I. Hodder, Symbolic and structural archaeology (Cambridge).

SIDRYs, R. I977. Mass-distance measures for the Maya obsidian trade, in (eds) T. K. Earle \& J. Ericson, Exchange systems in prehistony (New York).

TILLEY, C. I98I. Conceptual frameworks for the explanation of sociocultural change, in (eds) I. Hodder, G. Isaac and N. Hammond, Pattem of the past (Cambridge).

TRIGGER, B. G. 1980. Archaeology and the image of the American Indian, American Antiquity, xL, 662-76.

WOBST, M. 1977 . Stylistic behaviour and information exchange, University of Michigan Museum of Anthroplogy, Anthropological Paper, LXI, 31 7-42.

Agricultural innovation in the Early Islamic World by Andrew M. Watson. Cambridge Studies in Islamic Civilization. Cambridge: University Press, 1983. 260 pp., 18 figs., 8 maps. £25.00.

Carved Maori Burial Chests. A Commentary and a Catalogue by Aileen Fox. Bulletin No. I3, Auckland Institute and Museum, 1983. 52 pp., 51 figs, 71 pls. Available from: Auckland Institute and Museum, Private Bag, Australia, price $\$ 11.95+\$ 1.80 p \circlearrowleft$ 0 .

Sea Studies. Essays in honour of Basil Greenhill CB, CMG, on the occasion of his retirement. London: National Maritime Museum, 1983.83 pp., many illus. Ancient Egypt. A Social History by B. G. Trigger, B. J. Kemp, D. O'Connor \& A. B. Lloyd. Cambridge: University Press, 1983. 464 pp., 59 figs. $£ 27.50$ (\$49.50) cased, $€ 9.95$ (\$17.50) paper.

Quaternary Coastlines and Marine Archaeology: towards the prehistory of Land Bridges and Continental Shelves edited by P. M. Masters \& N. C. Flemming. New York, London, Paris: Academic Press, 1983.641 pp. $£ 25.00(\$ 42.00)$.

The Origins of Chinese Civilization edited by David N. Keightley. Berkeley, Los Angeles, London: University of California Press, 1983.617 pp., 66 figs, 14 tables, 12 maps. $€ 37.50$ (\$58.50) hard covers, $€ 12.75$ (\$19.50) paper.

The Rock Art of the North American Indians by Campbell Grant. The Imprint of Man series. Cambridge, London, New York: Cambridge Lniversity Press, 1983.61 pp., 24 figs., 121 pls., map. Ł.12.95.

continued on $p .44$ 